\title{
Psychological Well-Being of Patients with Breast Cancer: A Descriptive Study
}

\author{
Widyaningsih, $\mathrm{S}^{1}$, Istifaraswati, $\mathrm{A}^{2}$ \\ ${ }^{1}$ Nursing School, Faculty of Health Sciences, Universitas Muhammadiyah Purwokerto, \\ Indonesia \\ ${ }^{2}$ Nursing School, Faculty of Medicine, Diponegoro University, Indonesia \\ ${ }^{1}$ susanaw70@gmail.com
}

\begin{abstract}
The mental impact of cancer on patients is often severe. Patients who have been recently diagnosed with breast cancer tend to experience depression, emotional stress, disappointment, and even despair which later can damage their psychological well-being. This study aims to describe Psychological Well-being among breast cancer patients.134 breast cancer patients were recruited at the Out Patient Department (OPD) of Tugurejo Hospital Semarang city, Indonesia. The data were collected using Ryff Scale Psychological Well-being (RSPWB) questionnaire. Most of the respondents were middleaged, married, unemployed and had been diagnosed with early stadium of breast cancer. Results showed approximately half of the total respondents $(n=64 \%, 47.8 \%)$ experiencing low levels of psychological well-being over the entire period of the sickness. Among four subscales of psychological well-being, "positive relationship with others" subscale was reported to be very low among those respondents. However, almost two thirds of respondents perceived a higher degree of self-acceptance and life purpose while experiencing the illness. Nurses and healthcare providers need to be aware of the importance of counseling service and family/patients support group to improve the relationship of patients with others.
\end{abstract}

Keywords : : psychological well-being, breast cancer

\begin{abstract}
ABSTRAK
Dampak mental kanker pada pasien seringkali sangat berat. Pasien yang pertama kali didiagnosis menderita kanker payudara cenderung mengalami depresi, stres emosional, kekecewaan, dan bahkan keputusasaan yang kemudian dapat merusak kesejahteraan psikologis mereka. Penelitian ini bertujuan untuk menggambarkan Kesejahteraan Psikologis di antara pasien kanker payudara.134 pasien kanker payudara direkrut sebagai responden di ruang rawat inap bedah, Rumah Sakit Tugurejo kota Semarang, Indonesia. Data dikumpulkan dengan menggunakan kuesioner Ryff Scale Psychological Well-being (RSPWB). Sebagian besar responden adalah berusia setengah baya, menikah, tidak memiliki pekerjaan dan telah didiagnosis dengan stadium awal kanker payudara. Hasil penelitian menunjukkan sekitar setengah dari total responden $(\mathrm{n}=64 \%, 47,8 \%)$ mengalami tingkat kesejahteraan psikologis yang rendah selama menderita penyakit kanker payudara. Di antara empat subskala kesejahteraan psikologis, subskala "hubungan positif dengan yang lain" dilaporkan sangat rendah di antara responden tersebut. Namun, hampir dua pertiga responden merasakan tingkat penerimaan diri dan tujuan hidup yang lebih tinggi saat mengalami penyakit.
\end{abstract}


Perawat dan penyedia layanan kesehatan harus menyadari pentingnya layanan konseling dan kelompok dukungan keluarga / pasien untuk meningkatkan hubungan pasien dengan orang lain.

Kata kunci: Kesejahteraan psikologi, kanker payudara

\section{INTRODUCTION}

World Health Organization (WHO) (2018) reported that breast cancer ranks the fifth among cancer cases world wide and the first. The increase of new cancer cases is very high, approximately $43,3 \%$ and and almost one fifth were reported as the number of death caused by cancer (WHO International Agency for Research on Cancer, 2018). Almost three quarter of total death from breast cancer is dominated from low-income countries (Riskesdas Ministry of Health, 2013; WHO 2015). The total number of cancer cases in Indonesia ranked eighth in South East Asia and $23^{\text {th }}$ in Asia (Ministry of Health Indonesia, 2018). Furthermore, Ministry of Health reported that Yogyakarta has the highest prevelence of cancer patients (4.86 per 1.000 people), followed by West Sumatera and Gorontalo. Whereas breast cancer is still ranked in the first among other cases (58.256 cases) (Ministry of Health, 2018). Patients with breast cancer require comprehensive medical treatments, for instance surgery, chemoterapy, and radiotherapy. However, those modality treatments bring both positive and side effects.

Patients with breast cancer have to endure negative consequences when they undergo modality treatments. Pain, fatigue, and sexual disfunction are among the most distressful consequences. Not only physical effects, but also emotional distress. The patients suffer from emotional distress because the feeling of parting from their belonging, for example inability to work, economy difficulties, unability to perform activities, loss of breast, loss of family and spouse. Those later on will decrease their quality of life (QoL) and psychological well-being (PWB) (Winefield, Gill, Taylor, \& Pilkington, 2012; Fiorera, 2018). Psychological well-being is often defined as happiness, normally functioned or fulfilment of positive psychological function of the individual (Huppert, 2009). Ryff and Singer (1995) stated 6 dimensions of psychological well-being: self acceptance, positive relationship with others, outonomy, purpose of life, self development and mastery of environment.

Psychological well-being is very vulnerable in patients with chronic disease such as breast cancer. Breast cancer patients with high psychological well-being have a high level of QoL and have a great desire to maintain life domains related to their psychological well-being (Fiorera, 2018). Psychological well-being is very important to be studied because the emotional and psychological condition of a high individual can influence the course of their illness (Winefield et al., 2012). Based on the preliminary study carried out at Tugurejo Hospital, Semarang, Central Java Province, there were still a number of breast cancer patients who lacked of good relations with others, depended on those closest to them, did not participate actively and developed less potential within themselves. The purpose of this study was to measure the level of psychological wellbeing among patients with breast cancer.

\section{METHOD}

This research was a descriptive quantitative study. Patients with breast cancer who were hospitalized at Tugurejo hospital Semarang were used as a target population. 134 respondents were recruited using consecutive sampling method. The inclusion criteria were patients with breast cancer aged $>18$ years old and were able to communicate well. 
The data collection tool was the Ryff Scale Psychological Well-being Questionnaire, developed by Prof. Carol D. Ryff. The coefficient of validity of the questionnaire obtained was at a value of 0.66 to 1 (Ryff, 1995). Then the research instrument used in this study was declared valid. While the reliability test was performed using Croncbach's alpha coefficient the reliability test value obtained an alpha value of 0.805 The instrument was reported to be reliable if the instrument value was more than 0.7. Data analysis used univariate analysis. This study was approved by the Health Research Ethics Commission of the Tugurejo Hospital Semarang, No. 76 / KEPK / VII / 2018.

\section{RESULT AND DISCUSSION}

\section{A. Characteristics of Respondents (Table 1)}

Table 1. Demographic Data and Health Related Status of the Respondents $(\mathbf{n}=134)$

\begin{tabular}{lrr}
\hline $\begin{array}{l}\text { Respondent } \\
\text { Characteristics }\end{array}$ & Frequency (f) & Percentage (\%) \\
\hline Age (years old) & & \\
18-40 & 23 & 17.2 \\
$41-60$ & 98 & 73.1 \\
$>60$ & 13 & 9.7 \\
Education background & & \\
$\quad$ No schooling & 9 & 6.7 \\
$\quad$ Elementary & 45 & 33.6 \\
$\quad$ Junior high & 44 & 32.8 \\
Senior high & 23 & 17.2 \\
University & 13 & 9.7 \\
Marital status & & \\
Single & 2 & 1.5 \\
Married & 125 & 93.3 \\
Widow & 7 & 5.2 \\
Employment & & \\
Employed & 10 & 7.5 \\
Unemployed & 124 & 92.5 \\
Being diagnosed (years) & & \\
$0-2$ & 104 & 77.6 \\
3-4 & 30 & 22.4 \\
Stadium & & \\
1 & 43 & 32.1 \\
2 & 48 & 35.8 \\
3 & 35 & 26.1 \\
4 & 8 & 6.0 \\
\hline Total & 134 & 100.0 \\
\hline
\end{tabular}

Table 1 shows that most of the respondents were middle aged women $(73,1 \%, \mathrm{n}=98)$, majority of them had basic education $(83,6 \%, n=112)$ and unemployed $(92,5 \%, n=124)$. Approximately three quater of the total respondents were newly diagnosed and in the early stage of breast cancer.

Almost three quarter of the respondents in this study were middle aged which were in accordance with the total number of breast cancer patients in America (American Cancer Society, 2016). Being diagnosed with breast cancer and death of breast cancer were very prevalent among American women aged between 40 to 60 years old (American Cancer Society, 2016). Some previous studies found that patients were firsly diagnosed 
with breast cancer when they were above 45 years old. This condition often occurs because the risk of developing cancer increases with aging. The risk of genetics damage of body cells increases according with age. Moreover, elderly women would have more chance of being exposed to estrogen and progesteron, which were considered as predisposing factors of breast cancer (Hasson, Goldzweig, Braun \& Galinsky, 2010).

However, while most people from developed countries, such as the United States of America (USA), had high educational background, majority of our study respondents only had low or basic educational level. Individuals who take education at a higher level or university level, will have a better chance of gaining information about health issues. Furthermore, they will have a better awareness in making a choice, thus impacting on the emergence of their psychological well-being (Ryff and Singer, 1996; Sitepu \& Wahyuni, 2018). In this study most of the respondents (93.3\%) were married, the existence of a husband or partner on the respondent's side would make the respondents feel more secured and comfortable to share their stories and understand the respondent's situation. Respondents could also express their thoughts and feelings to spouses or husbands more easily than to other people (Mahleda \& Hartini, 2012). This situation would help them to relieve their emotional pressure. On the other hand, having no partner would eliminate sexual demands and orientation (Mahleda \& Hartini, 2012). This absence will alleviate both physical and psychological pressure among women who suffered from breast cancer (Maghfirah, 2012).

Employement is also important for all individuals. Breast cancer patients have decreased ability to work, those who initially work but after suffering from cancer themselves are more concerned with taking treatment rather than to work (Indrati, 2014). A person's psychological well-being can be influenced by economic ability, work, education, childhood life, and physical health. Housewives show psychological impact in the form of helplessness caused by not having a busy life so often think of the disease they suffer (Fratiwi, 2014).

In this study, most respondents had been diagnosed with breast cancer from 0 to 2 years ago. Duration of cancer diagnosis has a significant impact on the psychological well-being of patients. Impaired psychological function is often associated with symptoms of distress, both of which can cause difficulties in daily activities and increase supportive service needs that are not met (Liao, 2012). In this study only one third of the total respondents were diagnosed in the advanced stage. The psychological reaction of advanced breast cancer patients is greater than those in the early stage. They felt bad about themselves, unworthy and pesimistic towards their future. Some previous studies also reported that those in advanced stage of cancer were most likely to experience depressive syndrom. The patients had to endure alot of cancer therapies and its side effects, symptoms from the cancer development, and body function deterioration (Amin, 2008; Suharmillah, 2013).

\section{B. Results of Psychological Well-being Research in general (Table 2)}

Table 2. Level of Psychological Well-being $(n=134)$

\begin{tabular}{ccc}
\hline Psychological Well Being level & Frequency (f) & Percentage (\%) \\
\hline High & 70 & 52.2 \\
Low & 64 & 47.8 \\
\hline Total & 134 & 100.0 \\
\hline
\end{tabular}

Table 2. shows that about a half of the total had high Psychological Well-being, while the rest were low. 
The results showed that more than half of the respondents at Tugurejo District Hospital had a high Psychological Well-being value of 70 respondents (52.2\%). while 64 respondents $(47.8 \%)$ have low Psychological Well-being scores. The domain of psychological well-being with a high category in the domain of self-acceptance and life purpose is 85 respondents $(63.4 \%)$. Followed by the domain of personal growth and independence domain that is 80 respondents $(59.7 \%)$, then the domain of environmental mastery is 75 respondents (56\%), while the Psychological Well-being domain with the highest low category is in the domain of Positive Relations with Others that is 72 respondents $(53.7 \%)$.

Psychological Well-being refers to a person's feelings regarding all activities carried out by individuals that take place every day in which the process may experience fluctuations in thoughts and feelings that start from negative mental states to positive mental states, for example from trauma to acceptance life. Individual psychological wellbeing is influenced by age, sex, socioeconomic status and also social support (Ryff \& Singer, 2006). According to Ryff Psychological Well-being is divided into 6 dimensions, namely self-acceptance, positive relationships with others, independence, environmental mastery, life goals and personal growth (Ryff \& Singer, 2006).

In this study there are two highest domains: self-acceptance and life goals. Domain of self-acceptance refers to the ability of cancer patients to accept themselves as a whole. Individuals who rate themselves positively are individuals who understand and accept various aspects of themselves including good and bad qualities, can actualize themselves, function optimally and be positive towards the life they lead (Campton, 2005). Psychological conditions experienced by individuals depends on individual's ability o accept their condition positively (Fiorera, 2018). Therefore, people who have good selfacceptance will be able to have a positive attitude towards themselves and accept various aspects of themselves including good and bad natures (Wawan \& Dewi, 2011).

Then the domain of life's purpose refers to the life directions that patients with breast cancer set. Individuals who have a purpose and direction in life, feel and have a deep sense of meaning in their life today and have lived it, have confidence that gives purpose to life and have goals and goals in life, this causes breast cancer patients to have a high psychological well-being (Ryff, 1995). Patients who have high life goals will have a purpose in life and a sense of purpose, feel that there is meaning from present and past life, hold on to beliefs that give purpose to life, have desires and goals for life (Putri, 2012). Patients with breast cancer in the process of adaptation will experience many changes in their lives such as the process of loss, decreased health conditions associated with the stage of the disease, treatment and therapy carried out, and changes in the role due to illness. This can be felt as a stressor that will affect the meaningfulness of life (Wahidyanti, 2017).

Domain of personal growth is the ability of individuals to see themselves as individuals who are always growing and developing, having the ability to realize their potential. Personal growth cannot be achieved if the individual cannot create an environment that is in accordance with his personality. Patiens who have low personal growth will show that they do not feel any progress and self-potential from time to time. During the course of their illness they are very vulnerable to feel bored and not interested in life, unable to develop new attitudes or behavior (Dwipayama, 2010). Low selfacceptance will be supported by optimal individual personal growth, so that respondents' self-acceptance can be achieved through improvements that occur in themselves and their behavior every time (Maghfirah, 2012).

Indepence domain refers to the ability of breast cancer patients in making decisions and having high self-esteem. This domain states that individuals who have high autonomy 
are marked freely and are able to determine their own destiny (self-determination). Furthermore, they are able to regulate their own behavior, be independent, and fight or face social pressure. By having self independence, the patients are able to evaluate themselves and make decisions without the interference of others (Dwipayama, 2010).

Domain of environmental control indicates that the individuals are confident and competent in managing their environment. They can control the external activities that exist in their environment including regulating and controlling the situation of daily life. The patients who posses environment control are capable to create opportunities that exist in the environment, as well as to choose and create an environment that suits their personal needs (Fiorera, 2018). Good mastery of the environment will have the ability to create and adapt to the environment in accordance with their physical condition and the individual is able to deal with events outside that might occur in an individual's life (Sitepu \& Wahyuni, 2018).

The last domain is the lowest domain that is reported in this study is "close relationship with others". Individuals who are high in the dimension of positive relationships with others are characterized by being able to foster a warm and trusting relationship with others. In addition, the individual also has concern for the welfare of others, can show empathy and understand the principle of giving and receiving in interpersonal relationships. Conversely, individuals who are low in the dimension of positive relationships with others, show individuals have little close relationship and mutual trust with others (Sugianto, 2010; Wawan, 2010). In this study breast cancer patients only trust people they consider to be close and it is difficult to start a warm relationship with others, this is what causes the value in the dimensions of positive relationships with others to be low.

\section{Research Results from Every Psychological Well-being Domain (Table 3)}

Table 3. Frequency Distribution of Psychological Well-being Domain among Patients with Breast Cancer $(\mathbf{n}=\mathbf{1 3 4})$

\begin{tabular}{llccc}
\hline No & \multicolumn{1}{c}{ Domain } & $\begin{array}{c}\text { High } \\
\mathbf{n}(\boldsymbol{\%})\end{array}$ & $\begin{array}{c}\text { Low } \\
\mathbf{n}(\boldsymbol{\%})\end{array}$ & $\begin{array}{c}\text { Total } \\
\mathbf{n}(\boldsymbol{\%})\end{array}$ \\
\hline 1 & Self acceptance & $85(63.4)$ & $49(36.6)$ & $134(100)$ \\
2 & Positive relationships with others & $62(46.3)$ & $72(53.7)$ & $134(100)$ \\
3 & Independence & $80(59.7)$ & $54(40.3)$ & $134(100)$ \\
4 & Environmental control & $75(56)$ & $59(44)$ & $134(100)$ \\
5 & Purpose of life & $85(63.4)$ & $49(36.6)$ & $134(100)$ \\
6 & Self development & $80(59.7)$ & $54(40.3)$ & $134(100)$ \\
\hline
\end{tabular}

Table 3 shows Self acceptance and Purpose of life domains were the highest among other domains of psychological well-being. Whereas only 75 patients who reported to be able to have enviromental control (56\%).

\section{CONCLUSION}

Most breast cancer patients at Tugurejo District Public Hospital Semarang already have a High Psychological Well-being but the difference in the finding between one domain and the others is not significant. The patients reported to have a low positive relationship with others. Therefore nurses should pay more attention to the psychological condition of breast cancer patients, especially in the dimension of relationships with others. Breast cancer patients tend to be less caring and lack trust in other people except those they consider close. The provision of counseling about patients' illnesses and what 
patients feel is very productive. Nurses are able to facilitate the patients to build positive relationsships with other patients by creating a support group of breast cancer patients.

\section{REFERENCES}

American Cancer Society. (2016). Breast Cancer Facts \& Figures; 2015- 2016.

Amin, M. M. (2008). Sindrom depresif pada penderita kanker payudara. USU eRepository

Dwipayama. (2010). Penerapan rational emotive behavior therapy. Journal psychology.

Fiorera. (2018). Studi Desktiptid Psychological Well Being Pada Penderita Kanker Payudara di Komunits 3C Kota Bandung. Journal Psikologi.

Fratiwi, O. (2014). Analisis Dampak Psikologis Pengobatan Kanker Payudara di Rs Dr. Wahidin Sudirohusodo Kota Makassar.

Hasson, O., Goldzweig, G. Braun, M., \& Galinsky, D. (2010). Women with advanced breast and their spouses; Diversity of support and psychological. Psychooncology, 19(11), 1195-204. doi: 10.1002/pon.1678.

Huppert, F. A. (2009). Psychological well-being: Evidence regarding its causes and consequences. Applied Psychology: Health and Well-Being, (1) 2, 137-164 doi:10.1111/j.1758-0854.2009.01008.x

Indrati, R. (2014). Faktor Faktor Risiko Yang berpengaruh Terhadap Kejadian kanker Payudara Wanita.

Liao, M.M, Chen, S.C. (2012). Changes and Predictors of Unmet Suppotive Care Needs in Taiwanese Women With Newly Diagnosed Breast Cancer. Oncology Nursing Forum.

Magfirah. (2012). Penerapan Well-Being Therapy Untuk Meningkatkan Psychological Well-Being Pada Penderita Kanker Payudara

Mahleda, M., \& Hartini. (2012). Post-traumatic growth pada pasien kanker payudara pasca mastektomi usia dewasa madya. Jurnal Psikologu Klinis dan Kesehatan Mental, 1(2), 67-71p.

Putri, F. O. (2012). Hubungan Antara Gratitude Dan Psychological Wellbeing Pada Mahasiswa. Universitas Indonesia: Depok.

Ryff, C.D. (1995). Psychological well-being in adult life. Current Directions in Psychological Science, 4, 99-104. doi: 10.1111/1467-8721.ep10772395

Ryff, C. D., \& Singer, B.H. (2006). Know thyself and become what you are: A eudaemonic approach to psychological well-being. Journal of Happiness Studies, 13-39

Sitepu, Y. E., \& Wahyuni, S. E. (2018). Gambaran tingkat stres, ansietas, dan depresi pada pasien kanker payudara yang menjalani kemoterapi di RSUP H. Adam Malik Medan. Talenta Conference Series, 107-113

Sugianto. (2010). Model-model pembelajaran inovatif. Surakarta: Yuma Pustaka.

Wahidyanti. (2017). Pengaruh Logoterapi Terhadap Kesejahteraan Psikologis Pada Pasien Kanker Payudara Di Rumah Sakit Tk Ii Dr. Soepraoen Malang.

Wawan, A., \& Dewi, D. (2011). Teori dan pengukuran pengetahuan sikap dan perilaku manusia. Nuha Medika: Yogyakarta. 
Winefield, H. R., Gill, T. K., Taylor, A. W., \& Pilkington, R. M. (2012). Phychological well-being and psychological distress: Is it ncessary to measure both?. Psychology of Well-Being: Theory, Research and Practice, 2.

World Health Organization. (2018). International Agency for Research on Cancer. Latest global cancer data: Cancer burden rises to 18.1 million new cases and 9.3 million cancer deaths in 2018. Accessed April 2018. https://www.iarc.fr/featurednews/latest-global-cancer-data-cancer-burden-rises-to-18-1-million-new-cases-and9-6-million-cancer-deaths-in-2018/ 